\title{
ANALISIS BIAYA KEUNTUNGAN DEVELOPER DARI HARGA JUAL BERBAGAI TIPE RUMAH PADA BANGUNAN PERUMAHAN
}

\author{
Wahyu Ramadhan ${ }^{1}$ dan Yervi Hesna ${ }^{2}$
}

\begin{abstract}
ABSTRAK
Kawasan perkotaan yang berkembang pesat dengan beragam aktivitas menyebabkan kebutuhan masyarakat akan rumah menjadi meningkat. Alternatif mencapai keinginan tersebut yaitu dengan membeli rumah dari pihak pengembang perumahan. Developer atau pengembang perumahan akan berusaha menyediakan rumah dengan berbagai tipe rumah yang diminati oleh masyarakat. Penelitian ini bertujuan untuk mengetahui identifikasi biaya yang diperhitungkan kemudian didapatkan titik impas serta keuntungan tiap tipe rumah dengan mengambil data 3 (tiga) tipe rumah yang berbeda di Kota Pekanbaru. Dari hasil analisa break even point untuk rumah tipe 40/128 $\mathrm{m}^{2}$ mencapai titik impas pada Rp.3.232.600.000 (18 Unit), Tipe 75/120 m² Versailes sebesar Rp.826.960.000 (2 unit), dan tipe 150/155 m² Lux sebesar Rp.2.866.200.000 (3 unit). Berdasarkan hasil analisa break even point, maka diperoleh keuntungan dari tiap tipe rumah masing-masing yaitu sebesar Rp.1.201.892.432 (Tipe 40/128 m²), Rp.2.300.483.160 (Tipe 75/120 $\mathrm{m}^{2}$ Versailes), dan Rp 4.838.821.300 (Tipe 150/155 $\mathrm{m}^{2}$ Lux). Hasil penelitian menunjukan bahwa membangun rumah dengan tipe dan ukuran yang kecil, developer akan mendapatkan keuntungan yang lebih kecil dibandingkan dengan membangun rumah dengan tipe dan ukuran menengah dan besar. Dengan menjual rumah tipe 75/120 $\mathrm{m}^{2}$ keuntungan developer yang diperoleh hanya sebesar 20,66\% dibandingkan dengan membangun tipe rumah $75 / 120 \mathrm{~m}^{2}$ Versailes dan tipe rumah 150/155 $\mathrm{m}^{2}$ didapatkan keuntungan sebesar 95,08\% dan 69,51\%
\end{abstract}

Kata kunci : Biaya, Break Even Point, Keuntungan, Developer.

\section{PENDAHULUAN}

\subsection{Latar Belakang}

Kota Pekanbaru sebagai ibukota provinsi Riau, dengan semakin pesat pertumbuhan dan perkembangan penduduknya yang mengakibatkan banyaknya muncul para pengembang perumahan untuk menyediakan rumah atau perumahan sebagai tempat tinggal. Pihak pengembang atau penyedia perumahan dapat berasal dari pihak pemerintah, swasta maupun dari masyarakat itu sendiri. Rumah yang dikembangkan mulai dari rumah tipe sangat sederhana sampai tipe rumah mewah. Para pengembang perumahan biasanya lebih tertarik mengembangkan tipe rumah mewah (untuk golongan menengah ke atas) karena keuntungan yang didapatkan lebih bagus dibandingkan jika mengembangkan tipe rumah sederhana. Namun disisi lain masyarakat lebih banyak membutuhkan tipe rumah sederhana sesuai kemampuan mereka. Kebutuhan masyarakat yang tinggi terhadap tipe rumah sederhana merupakan permasalahan bagi pemerintah dalam rangka meningkatkan kualitas kehidupan masyarakat. Para pengembang atau developer perumahan akan berupaya menawarkan rumah dengan membuat berbagai macam tipe rumah yang diminati oleh

\footnotetext{
${ }^{1}$ Mahasiswa Jurusan Teknik Sipil Fakultas Teknik Universitas Andalas, rwhyu3@gmail.com

${ }^{2}$ Staf Pengajar Jurusan Teknik Sipil Fakultas Teknik Universitas Andalas, yervi2005@ gmail.com
} 
masyarakat yang mana mempunyai nilai tinggi, terlihat menarik serta aspek pasar yang telah diperkirakan. Dengan demikian developer dapat mendapatkan biaya keuntungan yang diinginkan.

\subsection{Latar Belakang}

Tujuan yang ingin dicapai dalam penyusunan ini yaitu :

1. Mengetahui identifikasi biaya yang akan diperhitungkan dari tiap tipe rumah yang telah dibuat.

2. Mengetahui titik impas dan keuntungan yang diperoleh developer dari masing-masing tipe rumah dengan metoda break even point (BEP)

Penyusunan penelitian tentang analisa biaya keuntungan developer dari harga jual berbagai tipe rumah pada bangunan perumahan memiliki manfaat yaitu :menambah pengetahuan bagi penulis serta menjadi referensi bagi penelitian selanjutnya.

\subsection{Batasan Masalah}

Penelitian yang dilakukan memiliki batasan masalah sebagai berikut :

1. Penelitiandilakukanpada3 (tiga) tipe rumah yang berada di Kota Pekanbaru yaitu tipe40/128 $\mathrm{m}^{2}$,tipe $75 / 120 \mathrm{~m}^{2}$ Versailes, dantipe $150 / 155 \mathrm{~m}^{2}$ Lux dengan masing-masing lokasi tipe rumah yang berbeda.

2. Pengambilan data terbatas pada brosur pemasaran yang mencakup denah, tampak rumah, spesifikasi bangunan perumahan, dan daftar harga satuan pekerjaan mengacu pada basic price Kota Pekanbaru Triwulan 1 (April-Juni) Tahun 2013.

Perhitungan biaya belum termasuk biaya pekerjaan lingkungan perumahan (biaya trotoar, biaya jalan lingkungan perumahan, dan biaya pembuatan gerbang pintu/one gate system).

\section{DASAR TEORI}

\subsection{Rumah dan Perumahan}

Dalam Undang-Undang Nomor 1 Tahun 2011 tentang perumahan dan permukiman, perumahan adalah kumpulan rumah sebagai bagian dari pemukiman, baik perkotaan maupun pedesaan, yang dilengkapi dengan prasarana, sarana, dan utilitas umum sebagai hasil upaya pemenuhan rumah yang layak huni. Sedangkan yang dimaksud dengan permukiman adalah bagian dari lingkungan hunian yang terdiri atas lebih dari satu satuan perumahan yang mempunyai prasarana, sarana, utilitas umum, serta mempunyai penunjang kegiatan fungsi lain di kawasan perkotaan atau kawasan perdesaan. Sedangkan pengertian rumah dalam Undang - Undang Nomor 1 Tahun 2011 adalah bangunan gedung yang berfungsi sebagai tempat tinggal yang layak huni, sarana pembinaan keluarga, cerminan harkat dan martabat penghuninya, serta asset bagi pemiliknya.

\subsection{Jenis dan Bentuk Rumah}

\section{A. Jenis Rumah}

1) Rumah Komersial, yaitu rumah yang diselenggarakan dengan tujuan mendapatkan keuntungan

2) Rumah Umum, yaitu rumah yang diselenggarakan untuk memenuhi kebutuhan rumah bagi masyarakat berpenghasilan rendah.

3) Rumah Swadaya, yaitu rumah yang dibangun atas prakarsa dan upaya masyarakat

4) Rumah Khusus yaitu rumah yang diselenggarakan untuk memenuhi kebutuhan khusus 
5) Rumah Negara, yaitu rumah yang dimilki Negara dan berfungsi sebagai tempat tinggal atau hunian dan sarana pembinaan keluarga serta penunjang pelaksanaan tugas pejabat dan/atau pegawainegeri.

\subsection{Konsep Hunian Berimbang Perumahan}

Dalam Peraturan Menteri Perumahan Rakyat (Permenpera) No.10 Tahun 2012 tentang penyelenggaraan perumahan dan kawasan pemukiman dengan hunian berimbang merupakan peraturan wajib dari pemerintah bagi pihak pengembang yang akan membangun proyek hunian berskala kota dalam satu lokasi, yaitu membangun kawasan pemukiman yang dibangun secara berimbang dengan komposisi tertentu dalam bentuk rumah tunggal dan rumah deret antara rumah sederhana,rumah menengah dan rumah mewah, atau dalam bentuk rumah susun antara rumah susun umum dan rumah susun komersial. Komposisi perbandingan jumlah rumah sederhana,rumah menengah,dan rumah mewah sekurang-kurangnya perbandingannya dengan konsep 3:2:1. Maksud konsep 3:2:1 adalah 3 Rumah Sederhana : 2 Rumah Menengah : 1 Rumah Mewah.

\subsection{Developer (Pelaku Usaha) Perumahan}

Menurut ketentuan Undang-Undang Perlindungan Konsumen Pasal 1 ayat 3, memberikan pengertian pelaku usaha, yaitu : setiap orang perseorangan atau badan usaha, baik yang berbentuk badan hukum maupun bukan badan hukum yang didirikan dan berkedudukan atau melakukan kegiatan dalam wilayah hukum Negara Republik Indonesia, baik sendiri maupun bersama-sama melalui perjanjian menyelenggarakan kegiatan usaha dalam berbagai bidang ekonomi.

\subsection{Metoda Analisa Breakeven Point (BEP)}

Analisa break even adalah suatu cara atau teknik untuk mengetahui kaitan antara produksi, penjualan, harga jual, biaya, laba dan rugi. Dengan mengetahui perkaitannya, analisa break even dapat digunakan untuk membantu menetapkan sasaran perusahaan atau organisasi jasa. Pada analisa break even, kita perlu menghitung seluruh biaya yang diperlukan. Komponen biaya yang perlu dipertimbangkan antara lain :

1. BiayaTetap (fixed cost)

2. Biaya Variabel (Variable Cost)

Secara matematis tingkat break even dapat ditentukan dengan berbagai rumus, yaitu dengan pendekatan matematis. Untuk mencapai kondisi break even, maka penerimaan (revenues) harus sama dengan total biaya.

$$
\mathrm{BEP} \rightarrow \text { TotalRevenue }(\mathrm{TR})=\text { TotalCost }(\mathrm{TC})
$$

\section{ANALISIS DAN PEMBAHASAN}

\subsection{Analisa Komponen Biaya Perumahan}

\section{A. Biaya Tetap (Fixed Cost)}

Data perhitungan yang telah dilakukan untuk biaya tetap (fixed cost) dari masing-masing tipe rumah dapat dilihat pada tabel berikut : 
Tabel 3.1 Total Biaya Tetap Tiap Tipe Rumah

\begin{tabular}{|l|c|c|}
\hline \multicolumn{1}{|c|}{ Tipe Rumah } & Total Biaya Tetap (Fixed Cost) & Total Biaya Tetap/Unit \\
\hline Tipe $40 / 128 \mathrm{~m}^{2}$ & Rp. 1.025 .865 .568 & Rp.27.570.912 \\
Tipe $75 / 120 \mathrm{~m}^{2}$ Versailes & Rp. 488.668 .840 & Rp.63.833.605 \\
Tipe $150 / 155 \mathrm{~m}^{2}$ Lux & Rp. 1.566 .728 .700 & Rp. 158.922 .870 \\
\hline
\end{tabular}

Sumber : Perhitungan

\section{B. Biaya Variabel}

Biaya variabel dari masing-masing tipe rumah dapat dilihat pada tabel berikut :

Tabel 3.2 Total Biaya Variabel Tiap Tipe Rumah

\begin{tabular}{|l|c|}
\hline \multicolumn{1}{|c|}{ Tipe Rumah } & Biaya Variabel/unit \\
\hline Tipe $40 / 128 \mathrm{~m}^{2}$ & Rp. 122.878 .000 \\
\hline Tipe $75 / 120 \mathrm{~m}^{2}$ Versailes & Rp. 241.356 .000 \\
\hline Tipe $150 / 155 \mathrm{~m}^{2}$ Lux & Rp. 539.445 .000 \\
\hline
\end{tabular}

Sumber : Perhitungan

\subsection{Analisa Breakeven Point}

A. Break Even PointDalam Unit Impas (BEP Unit)

Rumusan untuk mendapatkan unit impas yaitu sebagai berikut :

$$
B E P(\text { unit })=\frac{\text { Biaya Tetap }}{\text { Harga Jual }- \text { Biaya Variabel }}
$$

Sehingga break even untuk masing-masing tipe rumah dapat dijabarkan pada tabel sebagai berikut :

Tabel 3.3 BEP (unit) Tipe Rumah

\begin{tabular}{|l|c|}
\hline \multicolumn{1}{|c|}{ Tipe Rumah } & BEP (unit) \\
\hline Tipe $40 / 128 \mathrm{~m}^{2}$ & 18 Unit \\
\hline Tipe $75 / 120 \mathrm{~m}^{2}$ Versailes & 2 Unit \\
\hline Tipe $150 / 155 \mathrm{~m}^{2}$ Lux & 3 Unit \\
\hline
\end{tabular}

Sumber : Perhitungan

B. Break Even PointDalamRupiah (BEV Rupiah)

Rumusan dalam mendapat breakeven dalam value dapat dijabarkan sebagai berikut,

$$
B E V(\text { Rupiah })=\frac{\text { Biaya Tetap }}{1-\left(\frac{\text { Biaya Variabel }}{\text { penjualan }}\right)}
$$

Sehingga break even untuk masing-masing tipe rumah dapat dijabarkan pada tabel sebagai berikut :

Tabel 3.4 BEV (Rupiah) Tipe Rumah

\begin{tabular}{|l|r|}
\hline \multicolumn{1}{|c|}{ Tipe Rumah } & \multicolumn{1}{c|}{ BEV (rupiah) } \\
\hline Tipe $40 / 128 \mathrm{~m}^{2}$ & $\mathrm{Rp} .3 .232 .700 .000$ \\
\hline Tipe $75 / 120 \mathrm{~m}^{2}$ Versailes & Rp.826.960.000 \\
\hline Tipe $150 / 155 \mathrm{~m}^{2}$ Lux & Rp.2.886.200.000 \\
\hline
\end{tabular}

Sumber : Perhitungan 


\subsection{Analisa Biaya Keuntungan}

Dalam tahap analisa break even, pengembang perumahan akan berusaha melihat pencapaian break even sebagai bahan pertimbangan agar tidak mengalami untung maupun rugi. Tetapi dalam bisnis suatu property, perusahaan atau pengembang perumahan akan berusaha mencapai keuntungan atau profit sebesar-besarnya dengan pencapaian unit yang dibuat melebihi analisa break even yang telah direncanakan, jika unit yang dibuat melebihi rencana unit pada break even point ( $\mathrm{Q}>\mathrm{Qbe})$, maka sudah pasti perusahaan mengalami keuntunganatau profit. Dari data yang telah didapatkan, maka biaya keuntungan yang diperoleh untuk masing-masing tipe rumah dapat dilihat pada tabel berikut :

Tabel 3.5 Profit Masing-Masing Tipe Rumah

\begin{tabular}{|c|c|c|c|c|c|}
\hline Tipe Rumah & Unit & $\begin{array}{c}\text { Harga Jual } \\
(\mathbf{R p})\end{array}$ & $\begin{array}{c}\text { Biaya Tetap } \\
(\mathbf{R p})\end{array}$ & $\begin{array}{c}\text { Biaya Variabel } \\
(\mathbf{R p})\end{array}$ & $\begin{array}{c}\text { Total Profit } \\
(\mathbf{R p})\end{array}$ \\
\hline Tipe $40 / 128 \mathrm{~m}^{2}$ & 39 & 180.000 .000 & 1.025 .865 .568 & 122.878 .000 & 1.201 .892 .432 \\
\hline Tipe $75 / 120 \mathrm{~m}^{2}$ & 8 & 590.000 .000 & 488.668 .840 & 241.356 .000 & 2.300 .483 .160 \\
\hline Tipe $150 / 155 \mathrm{~m}^{2}$ & 10 & 1.180 .000 .000 & 1.566 .728 .700 & 539.445 .000 & 4.838 .821 .300 \\
\hline
\end{tabular}

Sumber :Hasil Perhitungan

\subsection{Pembahasan}

Dari analisa biaya keuntungan, masing-masing tipe rumah dapat dilihat persentase keuntungan pada diagram berikut :

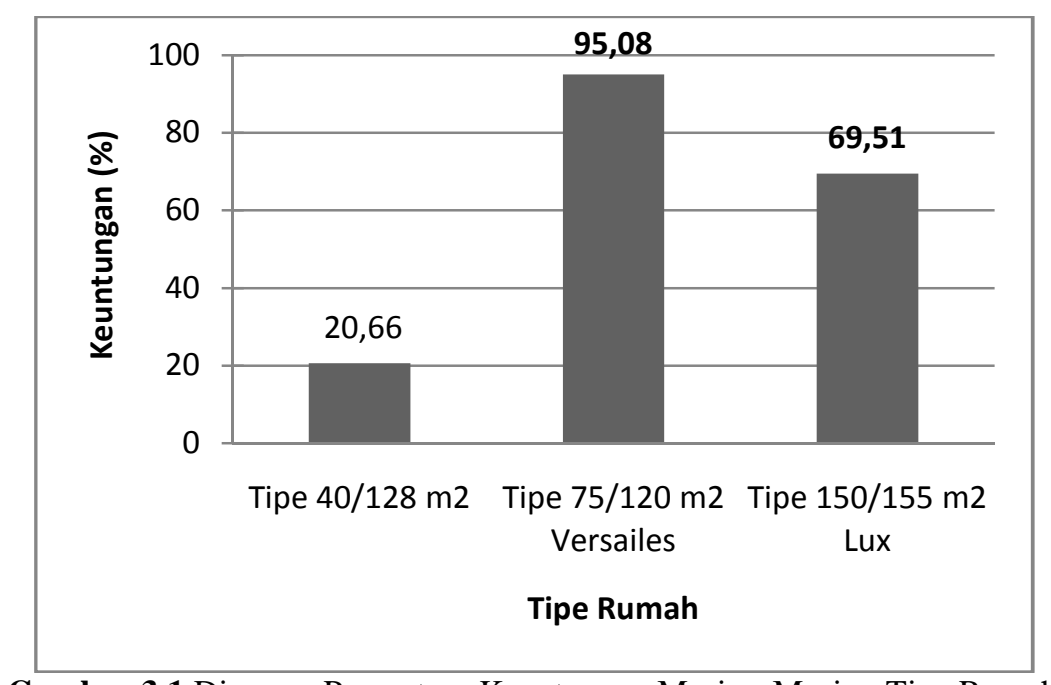

Gambar 3.1 Diagram Persentase Keuntungan Masing-Masing Tipe Rumah

Dari identifikasi biaya yang didapatkan dari perhitungan, maka dapat diperoleh komposisi biaya tetap dan biaya variabel dari tiap tipe rumah yang dapat dilihat pada tabel berikut :

Tabel 3.6 Komposisi Identifikasi Biaya Tiap Tipe Rumah

\begin{tabular}{|l|c|c|c|c|c|c|}
\hline \multirow{2}{*}{ Tipe Rumah } & \multicolumn{4}{|c|}{ Biaya Tetap } & Biaya Variabel & \multirow{2}{*}{ Total } \\
\cline { 2 - 6 } & Tanah & Sertifikasi & Maket & Pajak & RAB & \\
\hline Tipe $40 / 128 \mathrm{~m}^{2}$ & 86,91 & 1,74 & 0,11 & 0,535 & 10,70 & 100 \\
\hline Tipe $75 / 120 \mathrm{~m}^{2}$ & 65,75 & 0,56 & 0,27 & 0,34 & 33,06 & 100 \\
\hline Tipe $150 / 155 \mathrm{~m}^{2}$ & 73,59 & 0,34 & 0,12 & 0,34 & 25,61 & 100 \\
\hline
\end{tabular}


Keuntungan yang didapatkan dari tiap tipe rumah cenderung menempatkan keuntungan atau profit yang besar pada tipe 75/120 $\mathrm{m}^{2}$ dan tipe $150 / 155 \mathrm{~m}^{2}$ dengan masing-masing unit yang dibangun sebanyak 8 unit dan 10 unit. Sedangkan tipe rumah $40 / 128 \mathrm{~m}^{2}$,walaupun unit yang dibangun sebanyak 39 unit rumah, hanya mendapatkan keuntungan atau profit lebih kecil dari kedua tipe rumah lainnya. Dalam hal ini cenderung membuat pihak pengembang perumahan yang berada diperkotaan hanya mengembangkan suatu unit rumah yang akan mendapatkan profit sebesarbesarnya sehingga bagi masyarakat yang berpenghasilan rendah atau mempunyai keterbatasan daya beli susah mencari rumah diperkotaan dan mencari alternatif perumahan yang terletak dipinggir kota atau perbatasan kota yang memiliki perumahan yang sesuai dengan penghasilan masyarakat yang terbatas, walaupun akses dari pusat kota jauh serta fasilitas pendukung perumahan masih minim.

\section{KESIMPULAN}

Berdasarkan pembahasan dan tujuan terhadap penelitian yang telah dilakukan, dapat ditarik beberapa kesimpulan sebagai berikut:

1. Biaya yang harus diperhitungkan dalam penetapan biaya keuntungan masing-masing developer atau pengembang perumahan terdiri dari biaya tetap (fixed cost) dan biayavariabel.

2. Biaya Tetap meliputi biaya pengadaan tanah, biaya sertfikasi tanah, biaya maket rumah, biaya sewa kantor, dan biaya pajak property. Biaya Tetap pada rumah tipe 40/128 $\mathrm{m}^{2}$, tipe $75 / 120$ $\mathrm{m}^{2}$, dan tipe $150 / 155 \mathrm{~m}^{2}$ berturut-turut yaitu Rp.1.025.865.568, Rp.488.668.840, dan Rp1.566.728.700. Sedangkan biaya variabel meliputi keseluruhan dari rencana anggaran biaya masing-masing tipe rumah yaitu sebesar Rp.122.878.000,00/unit, Rp.241.356.000,00/unit, dan Rp.539.445.000,00/unit.

3. Perhitungan break even value berdasarkan masing-masing tipe rumah didapatkan titik impas pada rumah tipe 40/128 $\mathrm{m}^{2}$ sebesar Rp.3.232.700.000,00, tipe rumah 75/120 $\mathrm{m}^{2}$ sebesar Rp.826.960.000,00, dan tipe rumah 150/155 $\mathrm{m}^{2}$ sebesar Rp.2.886.200.000,00.

4. Biaya Keuntungan yang didapatkan pengembang perumahan pada tipe rumah $40 / 128 \mathrm{~m}^{2}$ sebesar Rp. 1.201.892.432,00 dengan membangun 39 unit rumah, rumah tipe 75/120 m sebesar Rp.2.300.483.160,00 dengan membangun 8 unit rumah, dan tipe 150/155 $\mathrm{m}^{2}$ sebesar Rp.4.838.821.300,00 dengan membangun 10 unit rumah.

\section{DAFTAR KEPUSTAKAAN}

Real Estate Indonesia, 2009, Aturan Pembangunan Sebuah Kawasan Perumahan.

Undang-Undang Republik Indonesia Nomor 1 Tahun 2011 Tentang Perumahan dan Kawasan Pemukiman

Peraturan Menteri Dalam Negeri Nomor 5 Tahun 1974 Tentang Ketentuan-ketentuan mengenai penyediaan dan Pemberian tanah untuk keperluan perusahaan

Blank,Tarquin, 2004, Engineering Economy, Mc.Graw Hill International, 6th Edition.

Standar Nasional Indonesia (SNI), Tata Cara Perhitungan Harga Satuan Pekerjaan Untuk Konstruksi Bangunan Gedung dan Perumahan, Badan Standarisasi Nasional. 